\title{
Hvordan forstår lærere utfordringer i praksisopplæringen? En studie av eksamenstekster
}

\author{
Gunnar Engvik ${ }^{1 *}$ \\ ${ }^{1}$ NTNU
}

\section{Sammendrag}

Hensikten med artikkelen er å unders $\varnothing$ ke hvordan deltakere i en videreutdanning for praksislærere i en videregående skole forstår utfordringer i praksisopplæringen. I artikkelen besvares to forskningsspørsmål: Hvilke utfordrende tema beskrives i eksamenstekstene? Hvilke tiltak identifiseres i diskusjonen om utfordrende tema i eksamenstekstene? Artikkelens utgangspunkt er en skolebasert videreutdanning gjennomført i vårsemesteret 2016 ved én av NTNUs universitetsskoler. Tematiske analyser av eksamenstekstene identifiserte fire utfordrende tema: klasseledelse, innsikt i skolekonteksten, relasjonen praksislærer praksisstudent og etiske dilemma. Diskusjonen rundt tiltak kan grupperes i fire tolkende koder: kommunikasjon, kartlegging av praksisstudentens livsrom, utvikling av praksislærerens kompetanse, og utvikling av praksisstudentens kompetanser. Deltakernes forståelse av utfordringer i praksisopplæringen knytter seg til to funn: 1) Betydningen av å utvikle et språk for å samtale med praksisstudenter, kolleger og lærerutdanningsinstitusjoner om erfaringer relatert til praksisopplæringen. 2) Temaer i praksisopplæringen som inngår i kulturelle-diskursive forhold (det semantiske rommet) og i makt (det sosiale rommet) er avgjørende for en profesjonell praksisopplæring.

Nøkkelord: intervensjon; universitetsskole; praksisarkitektur; praksisopplæring; studentpraksis i lærerutdanning

\begin{abstract}
The purpose of the article is to investigate how participants in a further education for internship teachers in a high school understand challenges in practice training. The article answers two research questions: What challenging topics are described in the exam texts? What measures identified in the discussion of challenging topics in the exam texts? The article's starting point is a school-based further education completed in the spring semester of 2016 at one of NTNU's university colleges. Thematic analyzes of the exam texts identified four challenging topics: Classroom management, insight into the school context, the relationship of practice teacher-practice student and ethical dilemma. Discussion of measures is divided into four interpretative codes: Communication, mapping of the student's living
\end{abstract}


space, developing the teacher's competence, and developing the student's competence. Participants' understanding of challenges in practice training relates to two findings: 1) the importance of developing a language for conversation with practicum-students, colleagues and teacher education institutions about experiences related to practice training. 2) Themes in practice training that are part of culturaldiscursive relationships (the semantic space) and in power (the social space) are essential for a professional practice training.

Keywords: Intervention; University School; practice architecture; practice training; student practice in teacher education

* Kontakt:

Gunnar Engvik

Institutt for lærerutdanning (ILU), NTNU

Tel.: 73598153 - sdf

E-post: gunnar.engvik@ntnu.no

\section{Innledning}

Det er ulike utfordringer knyttet til praksislærerens rolle og ansvar. På den ene siden skal praksislæreren ivareta lærerutdanningens ansvar for kvalifisering av lærerstudenter. På den andre siden er praksislæreren lærer for sine elever (Skagen, 2016). For praksislæreren kan studenter i praksisopplæring lett oppfattes som å være av sekundær interesse (Munthe \& Ohnstad, 2008). Oppfølgingen av praksisstudenter er også beskrevet som et relasjonelt forhold og som en prosess (Edwards-Groves, 2014), og den doble rollen til praksislæreren, som veileder og vurderer, er krevende (Hove, 2010). Praksislærere opplever dessuten at de utfører oppgaven som lærerutdannere uten nødvendige ressurser og støtte (Skagen, 2016). Lærerne i praksisskolene opplever sin profesjonelle identitet mer knyttet til å være lærer enn til å være lærerutdanner (Munthe \& Ohnstad, 2008; Nilssen, 2014; Skagen, 2016). En konklusjon kan være at mange praksislærere erfarer å ha for lite støtte og samarbeid om praksisansvaret (Heggen \& Thorsen, 2015), og at de opplever seg som «ensomme svaler» (Munthe \& Ohnstad, 2008). Det er en voksende interesse, både internasjonalt og nasjonalt, for å unders $\varnothing$ ke hvordan etablerte lærere gjennom videreutdanning kan få muligheter for videre profesjonell utvikling, og hvordan denne gruppen lærere utvikler sine forståelser som praksislærere (Jakhelln, Lund \& Vestøl, 2017; Raaen, 2017; Østern \& Engvik, 2016; Lunenberg, Dengerink \& Korthagen, 2014; Nilssen, 2014; Vanassche \& Kelchtermans, 2014).

Med dette som startpunkt ønsker jeg å undersøke hvordan deltakere i en skolebasert videreutdanning for praksislærere i en videregående skole beskriver utfordringer og diskuterer tiltak i forhold til disse, i eksamenstekster. Emneplanen for denne videreutdanningen ble utviklet med bakgrunn i rammeplan om et universitetsskolesamarbeid. ${ }^{1}$ Skolebasert kompetanseutvikling er et bærende element i emneplanen. Dette forutsatte at skolen, med ledelsen og alle lærerne, skulle delta aktivt i en utviklingsprosess på egen arbeidsplass. Målet med videreutdanningen var at lærere og ledere (deltakere) i en skolebasert modell skulle utvikle kunnskaper, forståelser og ferdigheter som praksislærere innenfor sitt fagområde. Utdanningen hadde dessuten som mål å bidra til skoleutvikling, og oppfølgingen av praksisstudenter måtte integreres i skolens faglige utviklingsarbeid. Et annet mål var å gi deltakerne økt forståelse for hvordan utvidet kompetanse som praksislærer kan bidra til å utvikle lærerstudentens kompetanse i et praksisfellesskap (Engvik \& Østern, 2017).

Tilegnelsen av kunnskaper, forståelser og ferdigheter som praksislærer foregår på ulike arenaer (Jakhelln, Lund \& Vestøl, 2017). Med denne videreutdanningen ønsket vi å koble det som foregår innenfor lærerutdanningen ved NTNU/ILU sammen med den kvalifiseringen av praksislærere som skjer $\mathrm{i}$ en skolebasert kompetanseutvikling. Det empiriske grunnlaget er eksamensbesvarelser fra 31

\footnotetext{
${ }^{1}$ Partene var NTNU, Trondheim kommune og Sør-Trøndelag fylkeskommune.
} 
studentgrupper med til sammen 101 deltakere, og artikkelens problemstilling er Hvordan forstår praksislærere utfordringer $i$ praksisopplæringen? Problemstillingens formulering -hvordan forstår praksislærere utfordringer i praksisopplæringen, avgrenses til hvilke utfordrende tema, og til diskusjoner av tiltak som er identifisert i eksamenstekstene. Denne avgrensingen gir at artikkelen belyser disse forskningsspørsmålene:

- Hvilke utfordrende tema beskrives i eksamenstekstene?

- Hvilke tiltak identifiseres i diskusjonen om utfordrende tema i eksamenstekstene?

\section{Teoretisk grunnlag}

Jeg starter med å presentere empiri om utfordringer og tiltak i praksisopplæring. Deretter følger en gjennomgang av modellen for den formative intervensjonen som artikkelens problemstilling bygger på. Videre presenteres teorien om praksisarkitektur (Kemmis \& Grootenboer, 2008; Kemmis et al., 2014), som er et grunnlag for analysen av eksamenstekstene. Så følger en presentasjon av studiets kommunikative rom, og en framstilling av teori om og forskning på læreres læring.

\section{Utfordringer og tiltak i praksisopplæringen}

Det første forskningsspørsmålet er: Hvilke utfordrende tema beskrives i eksamenstekstene? Forskningen til Sundli (2007) og Ottesen (2007) viser at de mest sentrale temaer i veiledningssamtalene er praksisstudentens handlinger og prestasjoner - på «hvordan». Sundli (2007) finner at mesteparten av veiledningstiden ble brukt til å argumentere for praktiske problemstillinger rundt undervisningsplaner og elevatferd. Ottesen $(2007$, s. 621) konkluderer med at et tilbakevendende tema i veiledningssamtalene var «What we are doing?». Helgevold, Næsheim-Bjørkvik \& Østrem (2014) hevder at oppmerksomheten i samtalene mellom praksislærer og praksisstudent har vært preget av «gjøringer», og at de aller fleste begrunnelser i denne samtalen er av praktisk karakter. Studier av samtaler mellom praksisærer og student i grunnskolelærerutdanningen, oppsummeres i hovedkategoriene: fag (om undervisningsfaget), elev (med problemer eller vist uvilje), gjøring («hvordan» organisere) og generelt (overordnede pedagogiske prinsipper) ( $\varnothing$ strem 2016). Forskere som Crasborn, Hennissen, Brouwer, Korthagen \& Bergen (2011) og Strong \& Baron (2004) finner at organisatoriske og undervisningsrettede tema er de mest framtredende i praksisveiledningen, og at fagdidaktiske tema ikke preger disse samtalene.

Det andre forskningsspørsmålet undersøker hvilke tiltak som kan identifiseres i diskusjonen om utfordrende tema i eksamenstekstene. De fleste studier av tiltak for å utvikle praksis i lærerutdanningen peker på behovet for å bygge bro mellom lærerutdanningens to arenaer, slik at praksisstudenten lærer at det å undervise er en grunnleggende sosial og relasjonell aktivitet som ideelt skjer $\mathrm{i}$ et kollegialt praksisfellesskap (Cochran-Smith \& Villegas, 2015; Cochran-Smith, Villegas, Adams, Chavez-Moreno, Mills \& Stern (2015). Diskursen om praksis i lærerutdanning preges i noen grad av at praksislærere i skolen har problemer med å identifisere seg som og bli akseptert som lærerutdannere (Bullough, 2005), at det må utvikles en ordning for å sertifisere praksislærere, og at det blir utformet etiske standarder for alle praksislærere (Lillejord \& Børte, 2017). Det andre forskningsspørsmålet kan sees i lys av forskning på lærerutdanning som profesjonsutdanning, og da med henblikk på hvilke sentrale kjennetegn som kan knyttes til oppgaven som praksislærer. Med støtte i Molander og Terum, (2008) og Lillejord og Børte (2017) har jeg formulert følgende kjennetegn ved praksislæreres yrkesut $\varnothing$ velses: felles kunnskapsbase, felles profesjonsspråk, opprettholde kvaliteten på eget arbeid som praksislærer, yrkesetiske retningslinjer. Smith (2016) løfter fram betydningen av praksislærerens profesjonskunnskap. Hun mener praksislærere er skolebaserte lærerutdannere, og at den største forskjellen mellom lærernes primærekspertise (det å undervise elever) og praksislærernes profesjonskompetanse, ligger $\mathrm{i}$ teoretisering av den praktiske kunnskapen de har om å undervise elever, og slik løfte sin tause kunnskap til et metanivå. En annen forskjell er at praksislærerne skal veilede voksne, som betyr at de har behov for kunnskap om voksnes læring, og særlig om uformell læring, på arbeidsplassen. 


\section{Teorien om praksisarkitekturer - et kommunikativt rom for dialog}

I boken Changing practices. Changing Education (Kemmis et al., 2014) er det visualisert en modell for en praksisteori. I videreutdanningen benyttet jeg en modifisert utgave av originalen, se Tabel. Det er spesielt to kjennetegn ved praksisteorier: kunnskapen som ligger i en praksis (den praktiske kunnskapen) og det dynamiske samspillet mellom individet (den som er i praksis og den som utøver praksis) og systemet (der praksis utøves) (Østern, 2016). Den valgte teorien er også en generell teori om utdanning og viser at de ulike praksisene i utdanningen er bundet sammen i praksisprosjekter. Teorien om praksisarkitektur omfatter en felles forståelse av det som gjøres, aktiviteter (doings), den karakteristiske diskursen, eller samtalene og tankene rundt aktiviteten (sayings), og forhold mellom mennesker og objekter som er involvert i praksisen (relatings). Når slike doings, sayings og relatings bindes sammen i et prosjekt, beskriver det en praksis (Lofthus, 2017).

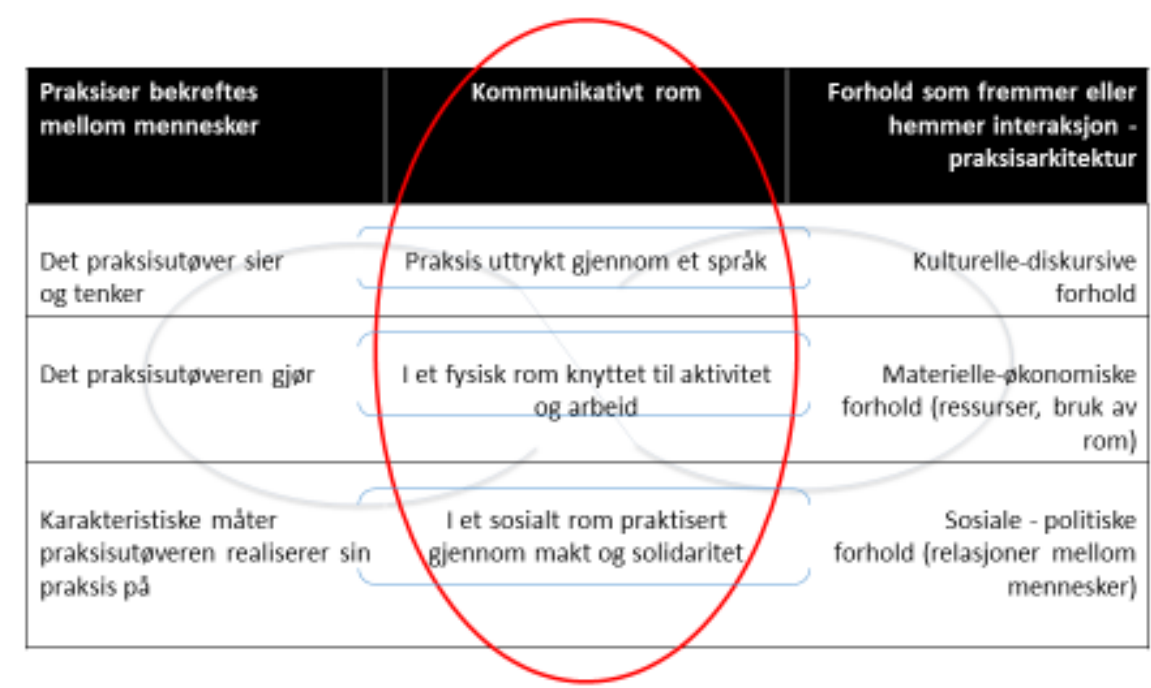

Figur 1. Modifisert modell for en praksisteori, basert på Kemmis et al. (2008) og bearbeidet av forfatter.

Venstre side i modellen omfatter mennesket som er i og som utfører praksis. Den forståelse Kemmis et al. (2008) legger til grunn for sin praksisteori, er at praksiser bekreftes mellom mennesker. I modellen er mennesket et produkt av ulike omstendigheter og oppdagelser, men det kan også endres av omstendigheter ( $\varnothing$ stern, 2016). I den midterste delen av figur 1 er det et kommunikativt rom for interaksjon. Det omfatter et semantisk rom realisert gjennom språk, et fysisk tid-rom realisert gjennom aktivitet og arbeid, samt et sosialt rom realisert i makt og solidaritet. I figurens høyre kolonne finner man begrepet «praksisarkitektur». Det refererer seg til teori om forutsetninger for praksis. Den organiseres $i$ tre forhold: Et kulturelt-diskursivt, et materielt- økonomisk og et sosialt-politisk. Praksiser er med andre ord avhengig av disse.

Det som binder modellens ulike deler sammen, er en uavbrutt responssløyfe. I denne responssløyfen ligger potensial for transformasjon av aktørenes praksisforståelser og av deres kunnskaper, samt deres mer generelle forståelser av utdanning. I de tre radene i høyre kolonne er det, avhengig av praksistradisjoner og hvilke praksislandskap man befinner seg i, forhold som fremmer og hemmer interaksjon.

Teorien om praksisarkitektur understreker betydningen av et kommunikativt rom for dialog, som er avgjørende for kompetanseutvikling og endring av forståelser. Slike teoretiske endringsmodeller er særlig aktuelle for dagens utdanningssystemer fordi de kan fungere som redskaper til å fornye og tilpasse seg en verden i akselererende forandring (Kemmis et al. 2014). 


\section{Formativ intervensjon}

Intervensjonen hadde som utgangspunkt å revitalisere praksis som en sentral del av lærerutdanningene. Tenkningen som praksisarkitekturmodellen representerer, kan ha stor innflytelse på det som skjer av læring i praksis. Et annet hovedprinsipp var at fagpersoner fra lærerutdanningen skulle bidra med innspill fra forskningsfronten. For å oppnå dette måtte det sørges for tilstrekkelig med tid til å lære, å engasjere ekstern ekspertise, å diskutere utfordrende problemer, å åpne for samhandlingsmuligheter i det profesjonelle fellesskap, å bidra til at undervisningsinnholdet, og dermed læringen, samsvarer med de politiske signaler samt påse at ledere organiserer læringsmuligheter for deltakere (Timperley, Wilson, Barrar \& Fung, 2007).

I intervensjonen ble arbeidsformen IGP (individuelt, gruppe, plenum) benyttet. I IGP får deltakere i en diskusjon muligheten til å tenke og skrive for seg selv (individ), presentere og diskutere tankene/ideene i en gruppe, og deretter presentert dette i plenum. IGP har deltakernes pedagogiske hverdag som startpunkt. Den er dialogbasert, og de som deltok i videreutdanningen, ble gitt muligheter til å kommunisere med hverandre (Postholm et al., 2013). Intervensjonen kan også knyttes til hvordan lesing av litteratur og samarbeidet om skriving av ulike dokumenter og den faglige eksamensteksten har bidratt til en lærende skole (Haugaløkken, Hoel \& Karlsen, 2006) og til skolebasert kompetanseutvikling (Fjørtoft, 2014). Skriveoppgavene ga deltakerne muligheter til å uttrykke sine behov for kompetanseutvikling (Timperley, 2011).

\section{Studiets kommunikative rom}

I videreutdanningen har vi forsøkt å konkretisere rom for dialog gjennom studiets seks kommunikative rom: plenum, grupperommet, skolerommet, veilederrommet, det personlige rommet og konferanserommet, se tabell 1. I rommene danner deltakerne et system for sosial samhandling (Kemmis et al., 2014).

Tabell 1. Studiets kommunikative rom.

\begin{tabular}{|c|c|c|}
\hline Kommunikative rom & System for sosial samhandling & Innhold i responssløyfer \\
\hline Plenum & Forelesere og praksislærere & $\begin{array}{c}\text { Kunnskapsgrunnlag, varierte } \\
\text { arbeidsformer }\end{array}$ \\
\hline Grupperommet & $\begin{array}{c}3 \text { praksislærere fra samme fagområde, } \\
\text { og grupperettleder(e). Veiledning fra } \\
\text { gruppeveiledere og lærere fra ILU }\end{array}$ & $\begin{array}{l}\text { Samarbeid, erfaringsutveksling og } \\
\text { læring. Planlegge og gjennomføre } \\
\text { utforsking, samt analyse, kritisk og } \\
\text { konstruktiv refleksjon }\end{array}$ \\
\hline Skolerommet & $\begin{array}{c}\text { Praksislærer, lærerstudent, } \\
\text { skoleledelse, kollega, gruppeveiledere, } \\
\text { elever, foreldre }\end{array}$ & $\begin{array}{l}\text { Utprøving, realisering, observasjon, } \\
\text { analyser, tilbakemelding }\end{array}$ \\
\hline Veilederrommet & $\begin{array}{c}\text { Praksislærer og gruppeveileder/lærere } \\
\text { fra ILU }\end{array}$ & $\begin{array}{l}\text { Veiledning, observasjon/refleksjon, } \\
\text { fortrolige tema }\end{array}$ \\
\hline $\begin{array}{l}\text { Det personlige } \\
\text { rommet }\end{array}$ & Praksislærer & $\begin{array}{l}\text { Selvstudium, lesing av tekster, utforming } \\
\text { av arbeidskrav, analyser og refleksjon }\end{array}$ \\
\hline Konferanserommet & $\begin{array}{c}\text { Praksislærere, kolleger, } \\
\text { gruppeveiledere, fagpersoner fra ILU }\end{array}$ & $\begin{array}{c}\text { Presentasjon av skisse til eksamenstekst, } \\
\text { opponenter, diskusjoner i sesjoner. } \\
\text { Utvikle eksamenstekst etter } \\
\text { konferansen. }\end{array}$ \\
\hline
\end{tabular}

I tabell 1 har jeg kort beskrevet hva som kjennetegner studiets kommunikative rom. De begrepene som går mest igjen i tabell 1 sin høyre kolonne, Innhold i responssløyfer, er: refleksjon, analyse, observasjon, læring og kunnskapsgrunnlag. 


\section{Læreres læring i skolen}

I intervensjonen utgjør resultatene av forskning på læreres læring i skolen et viktig kunnskapsgrunnlag. De viser at slik læring bør skje i nær tilknytning til praksis, og at den er betinget av at læreren har et metablikk på egen undervisningsutøvelse. Dette skjer best ved at erfaringene bearbeides i den pedagogiske hverdagen, og ved å møte ny kunnskap utvikles det dypere kunnskap, som i neste omgang vil kunne bidra til utvikling av egen yrkesutøvelse (Postholm \& Rokkones, 2012). Desimone (2009) hevder at forbedring av lærers praksis og ferdigheter fordrer at videreutdanningen preges av følgende fem momenter: innholdsfokus, aktiv læring, sammenheng, varighet og kollektiv deltakelse/eller samarbeid. Dessuten krever det at skolens ledelse skaper læringsmuligheter gjennom å sørge for tid, ressurser, å være oppmuntrende og å lede utviklingsprosessene. Likeledes er det vesentlig at slik videreutdanning har strukturer og prosesser som støtter mulighetene til å utvikle praksislærerens problemstillinger. Det anses også som viktig at utdanningen er dialogbasert, og at fagpersonene i utdanningen kommuniserer godt med de som tar utdanningen (Postholm et al., 2013).

Et annet forhold som virker inn på læreres læring, er at lærerne møter praksis med ulike tanker og forståelser av hva som kjennetegner profesjonell praksisopplæring. Deres læring er samtidig knyttet til den konteksten de befinner seg i. Læringen bygger dessuten på deres utdanning, praksiserfaringer, verdier og overbevisninger. Slike individuelle faktorer har betydning for hva, hvordan og hvorfor en lærer lærer i skolen (Opfer et al., 2011a). Ser vi på læreres læring ut fra et skoleorganisatorisk nivå, er det avgjørende at skolen evner å kommunisere en klar visjon, støtte lærernes profesjonelle utvikling og bidra til deres læring gjennom nettverksamarbeid mellom lærere. Dessuten er det vesentlig at skolen samarbeider med fagmiljøer som har kompetanser på skolens utviklingsprosjekt (Opfer, Pedder \& Lavicza, 2011b). Det teorigrunnlaget som er presentert ovenfor, var også med som grunnlag for utviklingen av studieplan og i gjennomføringen av intervensjonen.

\section{Metode}

\section{Grunnlaget for analyser}

Artikkelen bygger på analyser av 31 eksamenstekster, generert i en skolebasert videreutdanning av praksislærere i en videregående skole vårsemesteret 2016. Forskning på skriving som redskap for skoleutvikling peker på at skriving kan bidra til en lærende skole (Haugaløkken, Hoel \& Karlsen, 2006), og at skolebasert kompetanseutvikling kan knyttes til at «hele skolen skriver» (Fjørtoft, 2014). I tillegg anbefaler Timperley (2011) lesing og skriving for å uttrykke hva slags kunnskaper og ferdigheter - i denne sammenhengen praksislærere - trenger for å møte forventningene til kompetanseutvikling i praksisopplæringen.

Rammen for eksamensteksten var på rundt 2000 ord. Deltakerne var gruppert i triader ned basis i samme fagområde. Oppgaven besto i å utforme en eksamenstekst som satte utviklingen av kompetanser som praksislærere inn i en faglig kontekst. I teksten skulle deltakerne drøfte utfordringer fra egen arbeidsplass. Utfordringene skulle belyses gjennom en case fra praksisopplæring av lærerstudenter og studiets teorigrunnlag om praksisopplæring.

Utfordrende temaer i eksamenstekstene må sees i lys av hvilken kommunikasjon tekstene er bygd rundt. Samlet sett har rundt 80 prosent av kommunikasjonen i tekstene praksislærer - praksisstudent som tema. Rundt ti prosent har viet oppmerksomhet på kommunikasjonen mellom praksisstudent og elever. De $\varnothing$ vrige ti prosent av oppgavene har drøftet veiledning der kommunikasjonen er mellom skoleledere og lærere, skoleslaget/konteksten videregående skole og praksisstudent, og utvikling av en mal for veiledning av studenter (Engvik \& Østern, 2017).

Utformingen av en case var en del av studiets andre arbeidskrav. Skissen til eksamenstekst ble utviklet i en prosess med innspill fra to andre grupper og fra faglærere ved NTNU/ILU. Responsordningen hadde føringer for hvordan deltakerne skulle gi skriftlig respons til skissen. Denne delen av videreutdanningen 
støttes av forskning som viser at godt planlagt og gjennomført veiledning i skriveprosessen kan utvikle refleksjonsnivået i teksten (Dysthe, Hertzberg \& Hoel, 2010).

\section{Tematisk analyse}

Grunnlaget for analysene er kvalitative tekstanalyser som er skrevet i eller for konteksten skole- og utdanning (Widén, 2014). Riessman (2008) beskriver tematisk analyse som å svare på spørsmålet «hva?» dvs. hva skriver (sier, tegner, visualiserer) deltakerne, og at forskeren navngir temaene utfra sine teoretiske utgangspunkt. I denne studien er det gjennomført tematisk analyse med bruk av tre tolkningsnivåer, slik Fejes og Thornberg (2014) beskriver dem: Det første nivået er deskriptivt. Det andre er tolkende gjennom identifisering av temaer og mønster. Det tredje tolkningsnivået omfatter tolkning i lys av teori. Fremstillingen av første og andre tolkningsnivå er presentert i samme delkapittel.

\section{Forskningsetikk}

Dette forskningsprosjektet er godkjent av NSD den 18. mai i 2016, og 101 deltakere har i plenum godkjent at jeg bruker de anonymiserte eksamenstekstene som grunnlag for tematiske analyser. I godkjenningen av forskningsprosjektet er jeg forpliktet til ikke å publisere personopplysninger, og det skal ikke være mulig å føre opplysningene tilbake til enkeltpersoner. Slik sett er informantenes integritet ivaretatt. Et annet og kanskje det mest synlige forskningsetiske dilemmaet er min posisjon i forskningsprosjektet. Som beskrevet i innledningen har jeg utviklet studieplanen, og jeg har ledet videreutdanningen. Videre har jeg undervist, og sammen med to kolleger har jeg veiledet og sensurert eksamenstekstene. Ut fra dette kan min posisjon i forskningsprosjektet ikke betraktes som «nøytral», og jeg er ikke en utenforstående forsker (Jacobsen, 2011). Nærheten til en videreutdanning jeg var involvert i og til eksamenstekster jeg har veiledet og sensurert, er et forskningsetisk dilemma. For å skape distanse i analysearbeidet har jeg benyttet teoretiske begreper fra teorigrunnlaget om praksisarkitektur (Kemmis et al., 2014) og knyttet disse til tema i eksamenstekstene. Dette analytiske utenfra-blikket på tekstene som disse klassifiseres etter, kaller jeg for tolkende koder. Jeg er dermed også avhengig av et selvrefleksivt kritisk blikk på formuleringene i eksamenstekstene. Samtidig gir artikkelens teoriforankring (Kemmis et al., 2014) muligheter for å beskrive og drøfte oppgavebesvarelsene i lys av teori.

\section{Resultater og analyser}

\section{Utfordringer i eksamenstekstene - tematisk og tolkende analyse}

Gjennom analysen søker jeg svar på det første forskningsspørsmålet: Hvilke utfordrende tema beskrives $i$ eksamenstekstene? Analysene om utfordrende tema i eksamenstekstene kan ut fra deskriptive unders $\emptyset$ kelser systematiseres under følgende tolkende koder: Klasseledelse - forstått som å etablere et rolig miljø i klassen. Klasseledelse - forstått som å bidra til elevens faglige og sosiale utvikling. Innsikt $i$ skolekonteksten. Relasjon praksislærer - praksisstudent. Etiske dilemma: a) Praksisstudenten tar ikke veiledning, b) Skikkethet (se tabell 2).

Tabell 2. Utfordrende tema.

\begin{tabular}{cc}
\hline Eksempel på sitater som illustrerer tema i eksamenstekstene & $\begin{array}{c}\text { Tema - } \\
\text { tolkende koder }\end{array}$ \\
\hline Praksisstudent mangler kompetanse i kontroll og styring av klasser, og ferdigheter & \\
i rask korrigering. (Gruppe 1) & Klasseledelse - \\
forstått som å \\
Læordan håndtere elever som forstyrrer undervisningen? (Gruppe 2) \\
etablere et rolig \\
Praksisstudenter er i liten grad forberedt på oppgaven som kontaktlærere. \\
(Gruppe 13)
\end{tabular}




\begin{tabular}{|c|c|}
\hline $\begin{array}{c}\text { Praksisstudenten er ikke tilstrekkelig bevisst på å motivere elevene i } \\
\text { undervisningen. (Gruppe 11) }\end{array}$ & $\begin{array}{l}\text { Klasseledelse - } \\
\text { forstått som å }\end{array}$ \\
\hline $\begin{array}{l}\text { Praksisstudenten tar ikke i bruk arbeidsmåter som elevene er kjent med. (Gruppe } \\
\text { 30) }\end{array}$ & $\begin{array}{l}\text { bidra til elevens } \\
\text { faglig og sosiale }\end{array}$ \\
\hline Hvordan håndtere elever som forstyrrer $\mathrm{L}$ & \\
\hline \multicolumn{2}{|l|}{ Hvordan formidle det som skal læres og hvordan vurdere i faget? (Gruppe 5) } \\
\hline \multicolumn{2}{|l|}{$\begin{array}{l}\text { Det er viktig at praksisstudenten er bevisst egen tilstedeværelse i klasserommet. } \\
\text { (Gruppe 6) }\end{array}$} \\
\hline \multicolumn{2}{|l|}{ Viktig at praksisstudenten finner sin «egenart» som lærer. (Gruppe 12) } \\
\hline \multicolumn{2}{|l|}{ Praksisstudent mangler innsikt i videregående skole. (Gruppe 18) } \\
\hline Hvordan sikre god praksisopplæring på YF? (C & \\
\hline $\begin{array}{l}\text { Er det en frivillig sak for praksisstudenten å tilegne seg innsikt i skolens egenart? } \\
\text { (Gruppe 18) }\end{array}$ & skole \\
\hline \multicolumn{2}{|l|}{ Hvordan differensiere undervisningen for YF-elever? (Gruppe 31) } \\
\hline \multicolumn{2}{|l|}{$\begin{array}{l}\text { Praksisstudent er usikker, uerfaren og praksislærer oppfattes av studenten som } \\
\text { streng. (Gruppe 1) }\end{array}$} \\
\hline \multicolumn{2}{|l|}{ Viktig at praksisstudenten finner sin rolle som lærer. (Gruppe 9) } \\
\hline \multicolumn{2}{|l|}{ Relasjon mellom en ung praksislærer og en erfaren praksisstudent. (Gruppe 9) } \\
\hline Det er en ubalanse i forholdet mellom praksislærer og praksisstudent. (Gruppe & \\
\hline 11) & \\
\hline $\begin{array}{l}\text { Praksislærer må ha relasjonskompetanse og evne å opprette en god relasjon til } \\
\text { praksisstudent. (Gruppe } 23 \text { ) }\end{array}$ & praks \\
\hline \multicolumn{2}{|l|}{ Det blir mange velmenende råd fra praksislærer til praksisstudent. (Gruppe 20) } \\
\hline \multicolumn{2}{|l|}{ Det er viktig å få innsikt i praksisstudentens livsrom. (Gruppe 21) } \\
\hline \multicolumn{2}{|l|}{$\begin{array}{c}\text { Det er utfordrende for praksislærer på YF å veilede praksisstudentenes møte med } \\
\text { utfordrende elever og elever som har ulike diagnoser. (Gruppe 25) }\end{array}$} \\
\hline Praksisstudent vegrer seg mot å ta veiledning. (Gruppe 4) & Etiske \\
\hline Praksisstudenten tar ikke & Praksisstudenten \\
\hline $\begin{array}{l}\text { Praksislærer når ikke fram til praksisstudenten, og det er ulike oppfatninger av } \\
\text { situasjoner i klasserommet. (Gruppe 10) }\end{array}$ & $\begin{array}{c}\text { tar ikke } \\
\text { veiledning }\end{array}$ \\
\hline \multicolumn{2}{|l|}{$\begin{array}{l}\text { Skal jeg kontakte lærerutdanningen når studenten ikke har progresjon i } \\
\text { praksisperioden? (Gruppe 17) }\end{array}$} \\
\hline \multicolumn{2}{|l|}{$\begin{array}{l}\text { Hvordan ta tak i situasjoner der studenten opplever nederlag men ikke fullt ut } \\
\text { forstår hvorfor? (Gruppe } 27 \text { ) }\end{array}$} \\
\hline $\begin{array}{l}\text { Lærerstudenten har en umoden væremåte i kontakten med elevene, og kan dette } \\
\text { bero på studentens personlighet? (Gruppe 22) }\end{array}$ & $\begin{array}{l}\text { Etiske dilemma: } \\
\text { Skikkethet }\end{array}$ \\
\hline \multicolumn{2}{|l|}{$\begin{array}{l}\text { I en sak om skikkethet blir praksislærer beskyldt for å hindre studenten til å bli } \\
\text { lærer. (Gruppe 23) }\end{array}$} \\
\hline Hvordan utvikle skjønn i praksisopplæringen? (Gruppe 29) & \\
\hline Elever får lite veiledning fra praksisstudent i undervisningen. (Gruppe 8) & \\
\hline
\end{tabular}

Når oppmerksomheten flyttes over til tolkende analyse om utfordringer i eksamenstekstene, kan tolv sitater knyttes til klasseledelse med hovedvekt på klasseledelse som bidrar til elevens faglige og sosiale utvikling. Deltakerne etterlyser lærerstudentens forståelse for skoleslaget videregående skole, men også innsikt i forskjelligheten i elevgruppen i en skole med ti utdanningsprogrammer. Relasjonen praksislærer praksisstudent er viet oppmerksomhet i sju oppgaver. Noen utfordringer er beskrevet som forventninger til hvordan relasjonen bør være eller utvikles, mens andre utfordringer peker på konkrete sider ved relasjonen praksislærer praksisstudent som er utfordrende for praksislærere.

Etiske dilemma kan knyttes til to tema: Det ene retter oppmerksomheten mot praksisstudenter som «ikke tar veiledning», eller som «ikke ønsker veiledning». Praksislærerne oppfatter at de blir alene om å vurdere denne typen utfordringer. Det andre temaet gjelder vurderingen av praksisstudentens skikkethet, som behandles i fire eksamenstekster. Problemområdet praksisstudentens skikkethet har i de fire 
oppgavene ulike perspektiver. I den ene oppgaven pekes det på praksislærerens utøvelse av skjønn i vurderinger av skikkethet, i den andre beskrives situasjoner som kan oppstå når en praksislærer rapporterer til lærerutdanningsinstitusjonen at praksisstudentens skikkethet bør vurderes, mens et tredje perspektiv er usikkerheten rundt praksisstudentens personlighet. Praksislærernes bekymring for elevens læring og progresjon i praksisperiodene er det fjerde etiske dilemma som tas opp i eksamenstekstene.

\section{Utfordringer tolket i lys av teori}

Rommene finnes i språket som brukes (Lofthus, 2017). I diskusjonene er det tydelige spor etter et språk som forteller hva praksisstudenten gjør, som å «irettesette», "tar ikke i bruk kjente arbeidsmåter», «håndtere elever», og "hvordan formidle». Disse passasjene fra eksamenstekstene uttrykker et mønster i samhandlingen mellom elever og praksisstudent, og mellom denne og praksislæreren, som deltakerne mener kan hemme interaksjonen i den materielle virkeligheten de er en del av (Kemmis et al., 2014). Dette er praksis som bekreftes mellom mennesker i et fysisk rom som i denne sammenhengen er knyttet til praksisopplæringen.

Aktuelle spørsmål som knytter seg til sosiale-politiske forhold (se figur 1), kan være: "Hva kreves av kompetanse for å undervise i fag?» «Hva slags makt har ledere på ulike nivå?» «Hvilke former for lederskap er utviklet?» "Hvilke lojaliteter og hvilke solidariteter innvirker på arbeidsklimaet?» Østern (2016). I temaet «Klasseledelse forstått som å bidra til elevens faglige og sosiale utvikling», møter vi et fagspråk som beskriver relasjoner mellom mennesker og som uttrykker hvordan praksisstudenten realiserer sin praksis på: «ikke tilstrekkelig bevisst», "utvikle ferdigheter» og "finne sin 'egenart' som lærer». Det utfordrende temaet «Klasseledelse forstått som å etablere et rolig miljø i klassen» har et tilsvarende fagspråk som «mangler kompetanse» og «i liten grad forberedt». Dette er et fagspråk som også kan plasseres i det sosiale-politiske rommet. Sitatene viser hvordan praksislæreren skaper en forståelse av lærerstudentens praksis som bygger på et samspill i sosiale relasjoner innad i praksisen, men også i lys av andre praksiser (Kemmis et al., 2014; Lofthus, 2017). I studier av veiledningssamtaler i norsk grunnskole (Sundli, 2007; Ottesen, 2007; Helgevold, Næsheim-Bjørkvik \& Østrem, 2014) er hovedinntrykket at disse preges av «hvordan» eller "gjøringer», forstått som praksisstudentens handlinger og prestasjoner. Sett i lys av teorien om praksisarkitekturer (Kemmis et al., 2014) kan funnene i disse studiene tolkes som aktivitet og arbeid i et fysisk rom og «Det praksisutøveren gjør», se figur 1.

Utfordringene i temaet «Skolekontekst» er at praksisstudenten «mangler innsikt» og kompetanse til å «differensiere undervisningen for YF-elever». Det reises dessuten spørsmål som retter seg mot «[...] en bedre sikring av god praksisopplæring på YF», og mot hvem som har ansvaret for at "[...] praksisstudenten har tilegnet seg innsikt i skolens egenart.» Manglende kompetanse kan sees i et sosialt rom der praksis vises gjennom makt og solidaritet, mens problemstillingene retter seg mer mot systemer og hvilken makt de ulike ledernivåene har (Kemmis et al., 2014). Når deltakerne beskriver hvordan praksisstudenten realiserer sin praksis, som «usikker» og "uerfaren», skjer dette av fagpersoner som vet hvilken betydning disse begrepene har ( $\varnothing$ stern, 2016). Beskrivelser av relasjonen og samhandlingen praksislærer praksisstudent speiler samtidig hvilke sosiale relasjonsmønster som uttrykkes, og hvordan anerkjennelse og kritikk vises (Kemmis et al., 2014). Utsagn som "praksislærer oppfattes av studenten som streng», «relasjon mellom en ung praksislærer og en erfaren praksisstudent», og at «det er en ubalanse i forholdet mellom praksislærer og praksisstudent», kan fortelle om mulige spenninger og motsetninger som er til stede i disse relasjonene, og hva som kan fremme eller hemme interaksjonen i praksisarkitekturen (Østern, 2016).

Flyttes oppmerksomheten over på etiske dilemma, preges fagspråket av at praksisstudenten «vegrer seg mot å ta veiledning», "tar ikke veiledning», "har en umoden væremåte», "studenten opplever nederlag» og at "elever får lite veiledning». Sitatene har et språk som viser hvilke lojaliteter og hvilke solidariteter praksislæreren målbærer, og som innvirker på arbeidsklimaet (sosiale-politiske forhold). Diskursen rundt etiske dilemma favner flere utfordringer: «praksislærer når ikke fram til praksisstudenten», en bekymring om og eventuelt når praksislæreren skal «kontakte lærerutdanningen når studenten ikke har progresjon i praksisperioden» og «hvordan utvikle skjønn i praksisopplæringen». 
Det stilles for $\emptyset$ vrig spørsmål ved «studentens personlighet». Deltakerne er i diskursen rundt etiske dilemma opptatt av sosiale-politiske forhold, som omfatter makt og utøvelse av makt og hvilke former for lederskap som er utviklet i vurderinger rundt praksisstudentens skikkethet (se Østern, 2016).

Et annet trekk som beskriver relasjonen praksisstudent praksislærer, er den normative diskursen som er relatert til både kulturelle-diskursive og sosiale-politiske forhold (Sjølie, 2016). Deltakerne peker på mangler ved studentens praksis, men også på relasjonen sett fra praksislærerens perspektiv. Samtidig har noen deltakere fors $\varnothing$ kt å innta praksisstudentens perspektiv, noe vi kan tolke ut fra utsagnet «praksislærer oppfattes av studenten som streng».

I en utfordrende sak knyttet til skikkethet blir praksislæreren beskyldt for å hindre studenten i å bli lærer. Dette er et eksempel på temaer innenfor utdanningssystemet med høy status under sosialepolitiske forhold. Slike temaer har prioritet gjennom styringsdokumenter og praksistradisjoner og de preges av hva slags makt en praksislærer kan utøve i lærerutdanningen ( $\varnothing$ stern, 2016).

\section{Diskusjon}

\section{Diskusjonen om utfordrende tema - tematisk og tolkende analyse av tiltak} I denne delen undersøker jeg det andre forskningsspørsmålet: Hvilke tiltak identifiseres i diskusjonen om utfordrende tema i eksamenstekstene? Når det gjelder analyser ut fra et deskriptivt analysenivå, viser jeg til vedlegg, tabell 3. Denne analysen av temaer har gitt fire tolkende koder:

- Kommunikasjon

- Kartlegge studentens livsrom

- Utvikle praksislærerens kompetanser

- Utvikle lærerstudentens kompetanser

I den tolkende analyse av tiltak som kan grupperes under koden kommunikasjon, nevnes språket som det viktigste tiltaket for å møte utfordrende situasjoner. Her er teorien til Kemmis og Grootenboer (2008) om praksisarkitekturer og spesielt responssløyfen mellom praksis og arkitekturer, brukt av deltakerne for å beskrive hvordan man kan utvikle praksislærerens kompetanse. Å bygge bro mellom praksis i lærerutdanningen og undervisningen på campus (mellom «to verdener») bør skje i et kollegialt fellesskap. Hensikten er ifølge Cochran-Smith et al. (2015) å fremme lærerstudentens forståelse av undervisning som en grunnleggende sosial og relasjonell aktivitet. I eksamenstekstene beskrives dette kollektive fellesskapet i lys av et kommunikativt rom, se figur 1. Dette rommet fremmer utvikling fordi praksisstudent og praksislærer kan inkorporere hverandres kunnskap for å skape ny innsikt (Kemmis et al., 2014). Deltakere mener dessuten det er viktig å ta i bruk det kommunikative rommet for å bygge relasjoner mellom lærerstudent og praksislærer. En gruppe peker på at det kommunikative rommet også kan tas i bruk for å utvikle relasjoner mellom praksisstudenter og elever.

Som skolebaserte lærerutdannere har profesjonskunnskap betydning for praksislærerne yrkesutfoldelse (Smith, 2016). Slik sett er det interessant at tre grupper diskuterer kartlegging av praksisstudentens livsrom som et mulig tiltak i praksisopplæringen. Peavy er opptatt av at nærvær er den mest verdifulle gaven man kan gi til en annen, både $\mathrm{i}$ hverdagslivet og i veiledningssituasjonen. Veiledningens livsrom er stort, og Peavy peker på at veiledning må være et felles prosjekt mellom praksislærer og praksisstudent (Ahlbom \& Østern, 2016).

Av andre tema som diskuteres, mener deltakerne det er viktig å utvikle praksislæreres kompetanser generelt og i rollen som praksislærer spesielt, se vedlegg tabell 3. Det er imidlertid ulike forståelser av hvilke kompetanser som bør utvikles. Noen peker mot teorier og modeller, så som «dramatisk tilnærming» og «bruk av praksisarkitektur» (sosiale-politiske forhold), mens andre retter seg mer mot det praksislæreren «sier og gjør» i praksisopplæringen (kulturelle-diskursive forhold). I en eksamenstekst Iøfter deltakerne fram maktperspektivet i praksisopplæringen, og tiltaket som diskuteres er å vektlegge «symmetri» i praksisopplæringen. 
Den fjerde koden er å «Utvikle praksisstudentens kompetanser». Konteksten for eksamenstekstene er en stor kombinert videregående skole med ti utdanningsprogram. De konkrete løsningene speiler utfordrende tema som kan knyttes til yrkeslærerutdanningen eller til praktisk-pedagogisk utdanning (PPU). Deltakerne etterlyser praksisstudentens kunnskap om skolekonteksten og hvilke utfordringer YFlærere står overfor, og de stiller spørsmål om hvilket læringsutbytte en YFL-student sitter igjen med etter gjennomført praksis.

\section{Diskusjonen om tiltak tolket i lys av teori}

Å skape trygghet i praksisopplæringen gjennom kommunikasjon og et utviklet fagspråk er en utbredt forståelse i deltakernes selvrefleksjon. Betydning av det kommunikative rommet er mest uttalt når deltakerne diskuterer verdien av å løfte fram taus praksis/kunnskap til uttalt praksis/kunnskap, i fellesskap med praksisstudenten (Smith, 2016). Temaet kommunikasjon understreker at det fagspråket som brukes i samtaler mellom praksislærere, mellom praksisstudenter og mellom praksislærer og praksisstudent, kan via kulturelle-diskursive forhold bidra til å fremme eller hemme interaksjonen i praksisopplæringen (Kemmis et al., 2014).

For å gripe fatt i hva som fremmer og hemmer interaksjon i det kulturelle-diskursive "rommet» kan disse spørsmålene stilles: «Hvilke begreper utgjør det profesjonelle vokabularet til en spesifikk faggruppe?» og «Hvilke begreper kan brukes på meningsfylte måter?» (Østern, 2016). Den karakteristiske diskursen, samtalen og tankene rundt aktiviteten i det kulturelle-diskursive forholdet, omfatter hvilket fagspråk som brukes, og hvilke betydninger ulike begreper gis. Når denne diskusjonen tolkes i lys av forskning på lærerutdanning som profesjon og hvilke kjennetegn som kan være sentrale i praksislærerens yrkesut øvelse, er tiltak for å utvikle felles profesjonsspråk sentralt (Molander \& Terum, 2008; Lillejord \& Børte, 2017). Utviklingen av et felles profesjonsspråk bør, slik Smith (2016) ser det, knyttes til et kunnskapsgrunnlag med tema som voksnes læring og uformell læring på arbeidsplassen.

Noen grupper ser kartlegging av studentens livsrom som et mulig tiltak for å imøtekomme utfordringer i praksisopplæringen. Disse gruppene støtter seg til Peavys sosiodynamiske teori om veiledning. Dette tiltaket kan forklares som ønsket om å opprettholde kvaliteten på eget arbeid som praksislærere. Kartlegging av studentens livsrom kan også bidra til å utvikle praksislærerens kunnskapsbase og slik identifisere seg og bli akseptert som lærerutdanner (Bullough, 2005). Peavys teori om veiledning, som forventes å bidra til at den profesjonelle kompetansen som praksislæreren utvikler, kan i disse samtalene skape et større livsrom for deltakerne (Ahlbom \& Østern, 2016). Å delta i samtaler med kolleger om ulike sider ved veiledning av andre mennesker, er imidlertid utfordrende (Nilssen, 2014). I en veiledningskontekst kan man være sårbar, og i samtaler om erfaringer må praksislærere kunne vise pedagogisk takt og empati for å kunne forvalte sårbarhet på konstruktive måter. I teoribyggingen til Kemmis et al. (2008) kalles dette en 'site specific ontology', en væremåte som ivaretar kolleger, praksisstudenter og elever. Betydningen av kvalitet i praksislærerens evne til å lytte og observere og å veilede mot en profesjonell yrkesutfoldelse som er omgitt av tillit, understreker sosiale-politiske forhold $\mathrm{i}$ praksisopplæringen (Ahlbom \& Østern, 2016). Rollen som profesjonell praksislærer medfører å verdsette andre som gode samtalepartnere. Dette forteller noe om hvem som får snakke, hvem det blir lyttet til og hvordan likeverdighet blir tolket (Østern, 2016).

I diskusjonen av tiltak for å imøtekomme utfordringer i praksisopplæringen, har etiske dilemma en sentral plass. Deltakerne er opptatt av makt og utøvelse av makt og hvilke former for lederskap som er utviklet i vurderinger rundt praksisstudentens skikkethet. Ifølge Lillejord og Børte (2017) må det utvikles etiske standarder for alle praksislærere. Tiltakene som diskuteres rundt erfarte etiske dilemma framstår som en del av egen og praksisstudentenes kompetanseutvikling. Dette understreker behovet for yrkesetiske retningslinjer, som er et kjennetegn ved praksislærerens yrkesut $\varnothing v e l s e$ og profesjonskunnskap (Molander \& Terum, 2008; Lillejord \& Børte, 2017). Diskusjonene om utvikling av kompetansen til praksislærer og praksisstudent følger imidlertid ulike maktrelasjoner og former for lederskap (sosialepolitiske forhold). Mens praksislærernes kompetanseutvikling bør følge prioriteringer gjennom føringer i styringsdokumenter, som kompetansekrav til praksislærere og lokale forventninger til partnerskoler, er 
diskusjonen rundt kompetanseutviklingen til praksisstudenten mer preget av hvem som har ansvaret for å $\varnothing$ ke praksisstudentens innsikt i skolekonteksten. $\mathrm{Er}$ det lærerutdanningsinstitusjonen. Praksisskolen/praksislærerne eller praksisstudenten selv? Deltakerne reiser spørsmålene, men de konkluderer ikke på disse spørsmålene.

\section{Avsluttende kommentarer}

I denne artikkelen har jeg tatt for meg teori om praksisarkitektur og relatert dette til analyser og diskusjoner om utfordringer i praksisopplæring. Artikkelen har også analysert og diskutert deltakernes framstillinger av tiltak for å møte utfordrende tema i praksisopplæringen.

Jeg har vist fram hvordan en modell for formativ intervensjon ble valgt til ramme for den videreutdanningen som eksamenstekstene bygger på. Den teoretiske innrammingen er basert på en praksisteori utviklet av Kemmis og Grootenboer (2008). Disse prinsippene i intervensjonen hviler på en forståelse som ga deltakerne tilgang til en kompetanse i å analysere hva de og lærerstudentene sier og tenker, hva de gjør og hvordan de relaterer til andre i rollen som praksislærere (Kemmis et al. 2014; Lofthus, 2017; Østern, 2016). Vi kan betrakte teorien til Kemmis et al. (2014) som en pendling mellom individ- og systemnivå og går som en responssløyfe mellom de som deltar i interaksjonen i det kommunikative rommet.

Med utgangspunkt i problemstillingen «Hvordan forstår praksislærere utfordringer i praksisopplæringen?» har jeg drøftet deltakernes utfordringer og mulige tiltak for å utvikle praksisopplæringen. Ut fra analysene er det grunnlag for å hevde at praksisłærere forstår utfordringer $\mathrm{i}$ praksisopplæringen som kulturelle-diskursive og sosiale-politiske forhold. Det er mindre vekt på å forstå utfordringer i praksisopplæringen i lys av materielle-økonomiske forhold.

Jeg legger til grunn at eksamensoppgavene inneholder rike beskrivelser som understreker betydningen av å utvikle et felles språk - et profesjonsspråk, som et tiltak for å imøtekomme utfordringer i praksisopplæringen. Sentralt i deltakernes forståelser er at språket også beskriver former for lederskap som utøves, og hvilken makt som blir tillagt praksislærere. Gjennomgangen av studien understreker at deltakerne ser betydningen av å utvikle et profesjonsspråk for å samtale med praksisstudenter, kolleger, skolens ledelse og lærerutdanningsinstitusjoner om erfaringer relatert til praksisopplæringen. Ut fra teorien om praksisarkitekturer (Kemmis et al., 2014) er praksis uttrykt gjennom et språk for det praksisutøveren sier og tenker på individnivået en del av kulturelle-diskursive forhold på systemnivå.

Det andre jeg legger til grunn for svaret på problemstillingen, er at diskusjonen om tiltak, som kompetanseutvikling for deltakerne og lærerstudentene og ønsket om kompetanse i å behandle etiske dilemma, følger ulike former for lederskap og maktrelasjoner (sosiale-politiske forhold). I diskusjonene som er identifisert og sentrert rundt etiske dilemma, rettes et kritisk blikk mot svakheter på systemnivå $\mathrm{i}$ lærerutdanningen og mot behovet for kompetanseutvikling på dette området $\mathrm{i}$ egen skole. Tiltakene vil sette en standard for hva man kan forvente av praksislærere. De kompetansetiltakene som diskuteres og som skal bidra til å fremme praksisopplæringen i lærerutdanningen, er nødvendige forutsetninger for profesjonell yrkesutøvelse (Lillejord \& Børte, 2017). Sammen med et felles profesjonsspråk, favner $\varnothing n s k e r$ om kompetanseutvikling og yrkesetiske retningslinjer på mange måter et sett av forutsetninger for utvikling av praksisopplæringen i lærerutdanningen som en del av profesjonsutdanning. Arbeidet med artikkelen understreker at dette forskningsfeltet $b ø r$ vises større oppmerksomhet. 


\section{Litteratur}

Ahlbom, A. \& Østern, A.- L. (2016). Den veilededes livsrom - en studie av Vance Peavys sosiodynamiske teori for veiledning. I A.- L. Østern \& G. Engvik (Red.), Veiledningspraksiser i bevegelse: Skole, utdanning og kulturliv (s. 101-118). Bergen: Fagbokforlaget.

Bullough, R. V. Jr. (2005). Being and becoming a mentor: School based teacher educators and teacher educator identity. Teaching and Teacher Education, 21, 143-155.

Cochran-Smith, M. \& Villegas, A. M. (2015). Framing teacher preparation research: An overview of the field, part I. Journal of Teacher Education, 66(1) 7-20.

Cochran-Smith, M., Villegas, A. M., Adams, L., Chavez-Moreno, L., Mills, T. \& Stern, R. (2015). Critiquing teacher preparation research: An overview of the field, part II. Journal of Teacher Education, 66(2) 109-121.

Lillejord, F., Hennissen, P., Brouwer, N., Korthagen, F. \& Bergen, T. (2011). Exploring a two-dimensional model of mentor teacher roles in mentoring dialogues. Teaching and Teacher Educating, 27, 320331.

Desimone, L. M. (2009). Improving Impact Studies of Teachers' Professional Development: Toward Better Conceptualizations and Measures. Educational Researcher, 38(3), 181-199.

Dysthe, O., Hertzberg, F. \& Hoel, T. L. (2010). Skrive for å lære. Oslo: Abstrakt forlag.

Edwards-Groves, C. J. (2014). Learning teaching practices: the role of critical mentoring conversations in teacher education. Journal of Education and training studies, 2(2), 151-166. http://dx.doi:10.11114/jets.v2i2.343

Engvik, G. \& Østern, A.-L. (2017). Utdanning av praksislærere ved NTNUs universitetsskoler i 2016. Trondheim: NTNU-ILU. http://hdl.handle.net/11250/2466823

Fejes, A. \& Thornberg, R. (2014). Handbok i kvalitativ analys. Stockholm: Liber.

Fjørtoft, H. (2014). Hele skolen skriver. Skolebasert kompetanseutvikling i skriving som grunnleggende ferdighet. I K. Kverndokken (Red.), 101 skrivegrep. Om skriving, skrivestrategier og elevers tekstskaping (s. 343-358). Bergen: Fagbokforlaget.

Handal, G. \& Lauvås, P. (1999). På egne vilkår. En strategi for veiledning av lærere. Oslo: Cappelen.

Haugaløkken, O. K., Løkensgard Hoel, T. \& Karlsen, G. (2006). En lærende skole. Skriving som reiskap for skoleutvikling. Artikkel 1. Oslo: Utdanningsdirektoratet.

https://www.udir.no/globalassets/upload/skoleutvikling/artikkelstafett/skriving som reiskap for s koleutvikling.pdf

Heggen, K. \& Thorsen, K. E. (2015). Praksisopplæring - et felles prosjekt mellom høgskole og praksisskole? Norsk pedagogisk tidsskrift, 99(5), 362-374.

Helgevold, N., Næsheim-Bjørkvik, G. \& Østrem, S. (2014). Veiledningssamtaler i lærerstudentens praksisperioder - innhold og prosesser. I A. B. Reinertsen, B. Groven, A. Knutas \& A. Holm (Red.), Proceedings of FoU i praksis 2013 (s. 133-141). Trondheim: Akademika.

Hove, S. (2010). Bidrar praksisens utfordringer til yrkesetisk utvikling? Norsk pedagogisk tidsskrift, 94(5), 396-411.

Jacobsen, D. I. (2011). Hvordan gjennomføre undersøkelser? Kristiansand: Høyskoleforlaget.

Jakhelln, R., Lund, A. \& Vestøl, J. M. (2017). Universitetsskoler som arena for nye partnerskap og profesjonskvalifisering. I S. Mausethagen \& J.-K. Smeby (Red.), Kvalifisering til profesjonell yrkesutøvelse (s. 70-82). Oslo: Universitetsforlaget.

Kemmis, S. \& Grootenboer, P. (2008). Situating praxis in practice: Practice architectures and cultural, social and material conditions for practice. I S. Kemmis \& T. J. Smith (Red.), Enabling Praxis: Challenge for Education (s. 37-62). Rotterdam: Sense Publishers.

Kemmis, S., Wilkinson, J., Edwards-Groves, C., Hardy, I., Grootenboer, P. \& Bristol, L. (2014). Changing Practices, Changing Education. Singapore: Springer. 
Lillejord, S. \& Børte, K. (2017). Lærerutdanning som profesjonsutdanning-forutsetninger og prinsipper fra forskning. Oslo: Kunnskapssenter for forskning.

Lofthus, L. (2017). Bruk av teori for $\emptyset$ kt refleksivitet i praksis. Praksisarkitektur som rammeverk for å belyse forskerens plass i datagenereringen. I L. Frers, K. Hognestad \& M. Bøe (Red.), Metode mellom forskning og læring: Refleksjon i praksis (s. 35-55). Oslo: Cappelen Damm Akademisk.

Lunenberg, M., Dengerink, J. \& Korthagen, F. (2014). The Professional Teacher Educator. Roles, Behaviour and Professional Development of Teacher Educators. Rotterdam: Sense Publishers.

Molander, A. \& Terum, L.I. (2008). Profesjonsstudier - en introduksjon. I A. Molander \& L. I. Terum (Red.), Profesjonsstudier (s. 13-27). Oslo: Universitetsforlaget.

Munthe, E., \& Ohnstad, F. O. (2008). Ensomme svaler? Norsk pedagogisk tidsskrift, 6, 471-482.

Nilssen, V. (2014). Ny som praksislærer; motivasjon, inspirasjon og frustrasjon. Tidsskriftet FoU i praksis $8(2), 71-87$.

Opfer, V. D., Pedder, D. G. \& Lavicza, Z. (2011a). The role of teachers' orientation to learning in professional development and change: A national study of teachers in England. Teaching and Teacher Education, 27(2), 443-453. https://doi.org/10.1016/j.tate.2010.09.014

Opfer, V. D., Pedder, D. G. \& Lavicza, Z. (2011b). The influence of school orientation to learning on teachers' professional learning change. School Effectiveness and School Improvement, 22(2), 193214. https://doi.org/10.1080/09243453.2011.572078

Ottesen, E. (2007). Teachers "in the Making": Building Accounts of Teaching. Teacher Education: An International Journal of Research and Studies, 23(5), 612-623.

Postholm, M. B. \& Rokkones, K. L. (2012). Læreres profesjonelle utvikling: En review av forskning om hvordan lærere lærer. I M. B. Postholm (Red.), Læreres læring og ledelse av profesjonsutvikling (s. 21-50). Trondheim: Tapir Akademisk Forlag.

Postholm, M. B., Dahl, T., Engvik, G., Fjørtoft, G., Irgens, E. J., Sandvik, L. V. \& Wæge, K. (2013). En gavepakke til ungdomstrinnet? En undersøkelse av piloten for den nasjonale satsingen på skolebasert kompetanseutvikling. Trondheim: Akademika.

Raaen, F. D. (2017). Organisering og utbytte av praksisopplæringen. I S. Mausethagen \& J. C. Smeby (Red.), Kvalifisering til profesjonell yrkesutøvelse (s. 106-117). Oslo: Universitetsforlaget.

Riessman, C. K. (2008). Narrative Methods for the Human Sciences. Los Angeles: Sage Publications.

Sjølie, E. (2016). Å lære teori: En studie av lærerstudenters læringspraksiser. I A.-L. Østern \& G. Engvik (Red.), Veiledningspraksiser i bevegelse: Skole, utdanning og kulturliv (s. 45-58). Bergen: Fagbokforlaget.

Skagen, K. (2016). Kunnskapstyper og hegemonisk veiledningsstrategi i norsk veiledningsdiskurs. I A.-L. Østern \& G. Engvik (Red.), Veiledningspraksiser i bevegelse: Skole, utdanning og kulturliv (s. 59-80). Bergen: Fagbokforlaget.

Smith, K. (2016). Mentorer - skolebaserte lærerutdannere: Ansvar og krav. I A.-L. Østern \& G. Engvik (Red.), Veiledningspraksiser i bevegelse: Skole, utdanning og kulturliv (s. 197-209). Bergen: Fagbokforlaget.

Strong, M. \& Baron, W. (2004). An analysis of mentoring conversations with beginning Teachers: Suggestion and responses. Teaching and Teacher Education, 20(1), 47-57.

Sundli, L. (2007). Mentoring - A new mantra for education? Teacher and Teacher Education, 23, 201214.

Timperley, H. (2011). Realizing the power of professional learning. Berkshire, England: Open University Press.

Timperley, H., Wilson, A., Barrar, H. \& Fung, I. (2007). Teacher Professional Learning and Development: Best Evidence Synthesis Iteration [BES]. Wellington, New Zealand: Ministry of Education. Hentet fra: https://www.educationcounts.govt.nz/publications/series/2515/15341 
Vanassche, E. \& Kelchtermans, G. (2014). Teacher educators' professionalism in practice: Positioning theory and personal interpretative framework. Teaching and Teacher Education, 44, 117-127. https://doi.org/10.1016/i.tate.2014.08.006

Widén, P. (2014). Kvalitativ textanalys. I A. Fejes \& R. Thornberg (Red.), Handbok i kvalitativ analys (s. 177-193). Stockholm: Liber.

$\emptyset$ stern, A.-L. (2016). Betydningen av responssløyfer i veiledningsprosesser. En studie av en teori om praksisarkitektur i utdanning. I A.-L. Østern \& G. Engvik (Red.), Veiledningspraksiser i bevegelse: Skole, utdanning og kulturliv (s. 19-43). Bergen: Fagbokforlaget.

$\emptyset$ stern, A.-L. \& Engvik. G. (Red.) (2016). Veiledningspraksiser i bevegelse: Skole, utdanning og kulturliv. Bergen: Fagbokforlaget.

$\emptyset$ strem, S. (2016). Tematikken i veiledningssamtaler: forgrunn og bakgrunn. Acta Didactica Norge, 10(3), 1-16.

\section{Vedlegg}

Tabell 3. Forslag om tiltak på utfordrende tema.

Eksempel på sitater som illustrerer tiltak på utfordrende tema
Tema for tiltak - tolkende koder

\footnotetext{
Utvide veileders kommunikative rom. (Gruppe 4)

Viktig at det kommunikative rommet virker. (Gruppe 26) Bygge relasjoner. (Gruppe 1)

Fokus på relasjonsbygging mellom student og elever. (Gruppe 30)

Kommunikasjon

Ubalanse i forholdet mellom veileder og student. (Gruppe 11)

Veileder er ikke god til å lytte. (Gruppe 20)

Kartlegge studentens livsrom. (Gruppe 17)

Kartlegge studentens livsrom. (Gruppe 7)

Kartlegge studentens livsrom

Gjennomføre psykologisk kontrakt. (Gruppe 10)

Utvikle veilederrollen, viser til Kemmis. (Gruppe 5)

Utvide veileders kompetanse gjennom bruk av praksisarkitektur.

(Gruppe 4)

Sette av tid til kontaktlærerollen i veiledning. (Gruppe 13)

Veileder må selv reflektere over egen profesjonsut $\varnothing$ velse og egen læring. (Gruppe 12)

Dramaturgisk tilnærming. (Gruppe 3)

Forslag til mulig framgangsmåte i veiledersamtalen. (Gruppe 29)

Makt, ydmykhet, symmetri i veiledningen. (Gruppe 9)

Viktig at observatør har en detaljert plan og at dette er avtalt med den observerte på forhold. (Gruppe 24)

Få veisøker til selv å oppdage muligheter. (Gruppe 12)

At student observerer (minst) to faglærere, og tar del i planlegging

(eierfølelse). (Gruppe 6)

Hvilket læringsutbytte sitter en YFL-student igjen med etter gjennomført praksis? (Gruppe 28)

Student har liten kjennskap til skolekonteksten. (Gruppe 18)

Utfordringer som YF-lærere står i til daglig. (Gruppe 25)

Utvikle praksisstudentens kompetanser

Ta i bruk rommet ved oppstart av timer. (Gruppe 15)

Utvikle studentens strukturperspektiv, kulturperspektiv, fagdidaktisk perspektiv. (Gruppe 2)
} 